\title{
ENTEROPARASITIC OCCURRENCE IN FECAL SAMPLES ANALYZED AT THE UNIVERSITY OF WESTERN SÃO PAULO-UNOESTE CLINICAL LABORATORY, PRESIDENTE PRUDENTE, SÃO PAULO STATE, BRAZIL
}

Nair Toshiko TASHIMA(1) \& Maria Jacira Silva SIMÕES(2)

\begin{abstract}
SUMMARY
This study aims to analyze the enteroparasitic occurrence in children from 0 to 12 years old consulted at the University of western São Paulo Clinical Laboratory, Presidente Prudente, SP, Brazil, in relation to the socioeconomic profile of the attended children. Stool samples were examined and a questionnaire was applied with the objective of knowing the patient's age, sex, medical attendance, characteristic of the habitation, provisioning of water, dejection and domestic waste fates, use of footwear and clinical signs. The software EPI INFO 6 (Version 6.04b) was used for the elaboration of the data bank structure and analysis after previous data codification. Among 1,000 children analyzed, as many as $21.3 \%$ presented some kind of parasite. The most frequent protozoan was Giardia lamblia $(7.3 \%)$ followed by Entamoeba coli $(3.9 \%)$. The most frequent helminth was Enterobius vermicularis (1.9\%) followed by Hymenolepis nana (0.5\%). The most frequent protozoan association was Giardia lamblia / Entamoeba coli $(0.9 \%)$.
\end{abstract}

KEYWORDS: Enteroparasitosis; Children; Intestinal parasites.

\section{INTRODUCTION}

The world is a complex ecosystem in which the patterns of diseases vary from a country to another. Types and rates of human enteroparasitosis may be seen as a fingerprint once they correlate with per capita income, lifestyle, occupations and climate ${ }^{17}$.

Due to their low mobility and vulnerability, children under five years old reflect the enteroparasitic contamination in an specific area. Helminthiasis and protozoosis are infections with high incidence, and great impact on individual's health. Although enteroparasitosis are cosmopolitan, the occurrence is larger in tropical areas, and related to poverty. Despite the urbanization in Latin America in the last decades, $75 \%$ of the population lives in areas with occurrence of parasitosis, both in rural or urban zones ${ }^{3}$.

The intestinal infections by helminths may also be found in communities with high life style and culture ${ }^{8}$. Marginal communities in large cities, generally lacking sanitary infrastructure, are more liable to enteroparasitic infections, such as Ascaris lumbricoides, Trichuris trichiura, Entamoeba histolytica and Giardia lamblia ${ }^{29}$.

In tropical countries, the climate, in addition to uninformation and bad sanitary conditions, favors enteroparasitosis widespreading. Besides to become a problem of public health, it characterizes bad hygiene conditions, economic difficulties, uninformation on preventive actions, undernutrition, and lack of actions of authorities on public health ${ }^{8}$.

A well-fed person is more resistant to enteroparasitosis than a badfed one, because nutrition enhances immunological resistance. Thus, there is a greater occurrence of enteroparasitosis where hunger is endemic, with more severe infections and mortality rates ${ }^{20}$.

According to the World Health Organization, about 230 million children under five years old in developing countries have height deficit for their age; about 192 million show weight deficit and almost 50 million present weight deficit for the height ${ }^{11}$. Those data are in agreement to UNICEF - United Nations Fund for Childhood ${ }^{31}$.

The aim of this study was to analyze the occurrence of enteroparasitosis in children under 12 years old attended at the University of Western São Paulo (UNOESTE) Clinical Laboratory, Presidente Prudente, SP, Brazil, and investigate the relationship between the diagnostic and their social and living conditions.

\section{METHODS}

The study was performed with samples collected from one thousand children (some analyses were performed in samples taken in three alternated days) between 0 and 12 years old attended from January to

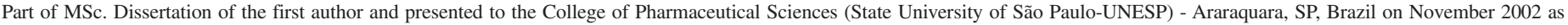
partial fulfillment for obtention of the title of MSc. in Clinical Analysis.

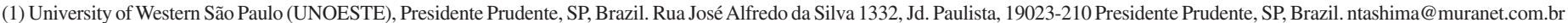

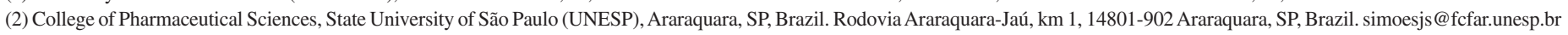




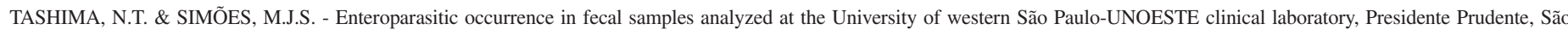
Paulo State, Brazil. Rev. Inst. Med. trop. S. Paulo, 46(5):243-248, 2004.

December 2001 at the Clinical Laboratory of the University of Western São Paulo (UNOESTE) - Presidente Prudente-SP. The patients' samples were analyzed at the laboratory after medical solicitation. A parent person responsible for the children signed an adhesion term consenting the participation in the research and answered a question any form about the social and habitational data. This research has been approved by Committee for Ethical Issues of the UNOESTE.

Among the information analyzed, special attention was taken with: the patient's age, sex, medical attendance, characteristic of the habitation, income, provisioning of water, destiny of dejection and garbage, use of footwear and pointed clinical signs.

The parasitological exams were executed systematically by means of three methods: spontaneous sedimentation ${ }^{15}$, Faust's method ${ }^{1,32}$ and Rugai's method $^{1,32}$. Some parasites were diagnosed by specific methods, when requested by the clinic professional, such as: the fresh exam of samples for observation of vegetative forms of protozoan ${ }^{32}$, the sieving and proglottids clarification for identification of Taenia $\mathrm{sp}^{32}$ and finally the Grahan's method ${ }^{32}$ for assessment of Enterobius vermicularis. At least two different examiners processed each sample, under supervision of a third examiner.

The database was elaborated by pre-coding the data in the EPIINFO 6 software (version $6.04 \mathrm{~b})^{33}$. The statistical analysis was accomplished by applying the qui-square $\left(\chi^{2}\right)$ test to evaluate the association between "diarrhea and parasitosis" and between "income and parasitosis", at $\mathrm{p}<$ 0.05 level.

\section{RESULTS}

Among the 1,000 children examined, $51.5 \%$ were female and $48.5 \%$ male. Most of the children (69.4\%) were between one and eight years old; $4.7 \%$ were less than one year old, while the remaining $(25.9 \%)$ were between nine and 12 years old. Of those children, $93.9 \%$ always used footwear, $4.4 \%$ sometimes and $1.7 \%$ did not use.

The children's family monthly income was more than two Brazilian federal minimum wages (one federal minimum wage $=$ about US $\$ 80.00$ on march 2004) for $84.4 \%$ of the children, $0.2 \%$ did not have income, $1.1 \%$ presented income lower than a minimum wage and $10.3 \%$ declined to answer.

The predominant medical attendance was public (Federal Health Unique System-SUS) with $92 \%$, followed by private plans with $8 \%(5.1 \%$ had Unoeste Saúde; $1.1 \%$ had Athia, 0.2\% Funrural and 1.6\% belonged to other plans).

With regard to habitation, $99.2 \%$ had toilet at home, which were of masonry for $97.3 \%$ and of wood-made for $2.5 \%$. Among the houses, $99.3 \%$ received water from public net system and $0.7 \%$ had access only to well water. For water consumption, $90.9 \%$ filtered water, $7.8 \%$ tap water, $0.7 \%$ boiled water and finally, $0.6 \%$ drank water from ceramic pots. The sewer of the houses was discarded in the sewerage system in $99.1 \%$ of the cases; $0.6 \%$ used cesspool and concrete cesspit $0.3 \%$. None made reference to discard in stream water.

With regard to the garbage withdrawal, $98.7 \%$ of the children lived in areas with public withdrawal, $0.6 \%$ lived where the garbage is burned, in $0.4 \%$ of the cases the garbage was untreated or collected and $0.3 \%$ buried their garbage.

The parasitic occurrence was analyzed according to two categories: monoparasitism and poliparasitism (Table 1). There was a predominance of monoparasitism (168 cases) in relation to the poliparasitism (45 cases). Among the children that presented monoparasitism, Giardia lamblia was the most frequent, followed by Entamoeba coli, Endolimax nana and Enterobius vermicularis. Among the children that presented poliparasitism, the most frequent association was between Giardia lamblia and Entamoeba coli, followed by Entamoeba coli and Endolimax nana (Table 1). When the occurrence of parasites was evaluated according to the age group, the children between one and four years old most frequently revealed absence of parasites, but it was the group that presented the largest occurrence of Giardia lamblia. However, except for Entamoeba coli that it was found in one case, no parasites were found in children with less than one year old. The most frequent helminth was Enterobius vermicularis, present in a child of the group from one to four years old, eleven children in the group from four to eight years old and seven cases between eight and 12 years old. The most frequent association was Giardia lamblia and Entamoeba coli, observed in five children of the group from four to eight years old, followed by three cases in children from one to four years and a case in children from eight to 12 years old. Other associations occurred in smaller frequency (Table 1).

From one thousand children, $77 \%$ did not present clinical symptoms, while $23 \%$ presented some symptom, mainly diarrhea, with 23 cases (Table 2). From 73 children that presented Giardia lamblia, 40 did not present symptom. In the remaining, the most frequent complaint was diarrhea ( 11 cases), followed by diarrhea and belly pain (10 cases).

The qui-square analysis among familiar income and presence of parasites revealed that those variables are not related $\left(\chi^{2}=1.43 ; \mathrm{p}=\right.$ $0.2324)$. On the other hand, the analysis between diarrhea and parasitism revealed that these variables are strongly related $\left(\chi^{2}=17.72 ; p<0.01\right)$ (Table 3).

\section{DISCUSSION}

Our results showed that among the children from 0 to 12 years old that had their feces analyzed in the Clinical Laboratory University of Western São Paulo (UNOESTE) after medical solicitation, 21.3\% had cysts or eggs of, at least, one parasite. The protozoa Giardia lamblia and the helminth Enterobius vermicularis were the most frequent parasites, with prevalence of $7.3 \%$ and $1.9 \%$, respectively. It should be emphasized that these values may be underestimated because not all the exams were accomplished in three samples, in alternated days. In an infected person, the cysts elimination of Giardia lamblia is not constant ${ }^{28}$, what could give negative results during some days. The effectiveness of parasitological exams of fecal samples to identify cysts showed $73 \%$ of positivity in the first exam and $100 \%$ in the fifth exam ${ }^{18}$. In addition, NAZER et al. (1993) detected $66 \%$ of positive cases in the first examination, and $100 \%$ in three examinations.

MACHADO et al. (1999) concluded that age, cultural and socioeconomical levels are related with giardiasis, what reflects on basic hygiene procedures. Most part of studied children received treated water 


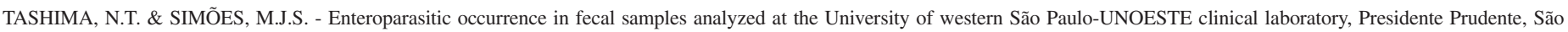
Paulo State, Brazil. Rev. Inst. Med. trop. S. Paulo, 46(5):243-248, 2004.

Table 1

Diagnosis of parasites by children's age. Presidente Prudente-SP, 2001

\begin{tabular}{|c|c|c|c|c|c|}
\hline \multirow[t]{2}{*}{ Parasites } & \multicolumn{5}{|c|}{ Ages } \\
\hline & $0 \vdash 1$ & $1 \vdash 4$ & $4 \vdash 8$ & $8 \longmapsto 12$ & Total \\
\hline Negatives & 46 & 305 & 243 & 193 & 787 \\
\hline Giardia lamblia & - & 40 & 16 & 17 & 73 \\
\hline Entamoeba coli & 1 & 10 & 14 & 14 & 39 \\
\hline Entamoeba histolytica & - & - & - & 1 & 1 \\
\hline Iodamoeba butschlii & - & - & - & 1 & 1 \\
\hline Endolimax nana & - & 3 & 7 & 9 & 19 \\
\hline Ascaris lumbricoides & - & 2 & 1 & - & 3 \\
\hline Hymenolepis nana & - & - & 2 & 3 & 5 \\
\hline Taenia sp & - & - & - & 1 & 1 \\
\hline Enterobius vermicularis & - & 1 & 11 & 7 & 19 \\
\hline Ancylostomid & - & 1 & - & 1 & 2 \\
\hline Schistosoma mansoni & - & - & 2 & - & 2 \\
\hline Trichuris trichiura & - & 1 & 1 & 1 & 3 \\
\hline (Total of the monoparasitism) & (1) & (58) & (54) & (55) & (168) \\
\hline Giardia lamblia / Entamoeba coli & - & 3 & 5 & 1 & 9 \\
\hline Giardia lamblia / Endolimax nana & - & 1 & 1 & - & 2 \\
\hline Giardia lamblia / Ascaris lumbricoides & - & 1 & - & - & 1 \\
\hline Giardia lamblia / Hymenolepis nana & - & - & - & 2 & 2 \\
\hline Giardia lamblia / Taenia sp & - & 1 & - & - & 1 \\
\hline I. butschlii / H. nana / A. lumbricoides / E. nana & - & - & 1 & - & 1 \\
\hline E. coli / E. nana / H. nana & - & - & - & 1 & 1 \\
\hline E. nana / E. coli / E. histolytica & - & 1 & 1 & - & 2 \\
\hline E. coli / E. nana & - & 1 & 3 & 3 & 7 \\
\hline G. lamblia / H. nana / T. trichiura & - & - & 1 & - & 1 \\
\hline E. coli / E. vermicularis & - & - & 2 & 1 & 3 \\
\hline E. nana / I. butschlii & - & - & 2 & - & 2 \\
\hline Strongyloides stercoralis & - & 1 & - & 1 & 2 \\
\hline E. coli / E. histolytica & - & 1 & - & - & 1 \\
\hline E. coli / T. trichiura & - & - & 1 & - & 1 \\
\hline A. lumbricoides / T. trichiura / S. stercoralis & - & - & 1 & - & 1 \\
\hline A. lumbricoides / E. coli & - & - & 1 & - & 1 \\
\hline E. coli / E. nana / A. lumbricoides & - & - & 3 & - & 3 \\
\hline G. lamblia / T. trichiura & - & - & 2 & - & 2 \\
\hline G. lamblia / T. trichiura / A. lumbricoides & - & - & - & 1 & 1 \\
\hline E. nana / E. vermicularis & - & - & - & 1 & 1 \\
\hline (Total of the poliparasitism) & - & (10) & (24) & (11) & (45) \\
\hline Total & 1 & 68 & 78 & 66 & 213 \\
\hline
\end{tabular}

from the public net in their houses, and the occurrence of giardiasis (7.3\%) agree to other studies stating that chlorination does not destroy adequately the parasite's cysts ${ }^{20}$.

PEREZ et al. (1997) and BRAGA et al. (1996), studying respectively Spaniards and Brazilians from northeast region observed a low prevalence of amebiasis in persons from six and 14 years old. On the other hand, KOBAYASHI et al. (1995) assessing samples from the city of HolambraSP, Brazil, population observed a higher number of positive cases in patients older than 16 years. In this work, we observed only one child from the group between eight to 12 years old with Entamoeba histolytica.

In this work the second most frequent protozoa was Entamoeba coli
(3.9\%) followed by Endolimax nana (1.9\%), which are indicators of social-sanitary conditions ${ }^{27}$ and have the same transmission way of Giardia lamblia.

According to FERREIRA et al. (2000), recent reductions in the prevalence of parasitosis are due to improvements in familiar incoming, the level of mothers' scholarship, improvement of habitations, sanitation, and access to health services. Although parasitoses have decreased in all social levels, it still has an inverse relationship with economic incoming. School children in Kenya showed prevalence of $87 \%$ of ancylostomiasis, $88 \%$ of trichuriasis and $31 \%$ of ascaridiasis ${ }^{29}$.

FERREIRA \& MARÇAL Jr. (1997), observed in the city of 


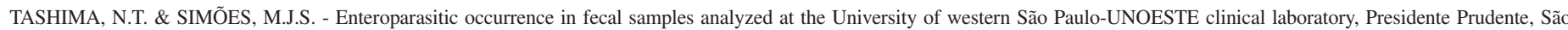
Paulo State, Brazil. Rev. Inst. Med. trop. S. Paulo, 46(5):243-248, 2004.

Table 2

Association between Enteroparasitic species and symptoms. Presidente Prudente-SP, 2001

\begin{tabular}{|c|c|c|c|c|c|c|c|c|c|}
\hline \multirow[b]{2}{*}{ Parasites } & \multicolumn{9}{|c|}{ Symptoms } \\
\hline & Diarrhea & Vomit & Belly pain & $\begin{array}{l}\text { Diarrhea } \\
\text { and vomit }\end{array}$ & $\begin{array}{c}\text { Diarrhea } \\
\text { and belly } \\
\text { pain }\end{array}$ & $\begin{array}{l}\text { Vomit and } \\
\text { belly pain }\end{array}$ & $\begin{array}{l}\text { Diarrhea, } \\
\text { vomit and } \\
\text { belly pain }\end{array}$ & None & Total \\
\hline Negative & 59 & 3 & 57 & 14 & 15 & 4 & 5 & 630 & 787 \\
\hline GL & 11 & 1 & 6 & 1 & 10 & - & 4 & 40 & 73 \\
\hline $\mathrm{EC}$ & 5 & - & 2 & - & - & - & - & 32 & 39 \\
\hline $\mathrm{EH}$ & - & - & - & - & - & - & - & 1 & 1 \\
\hline IB & - & - & - & - & - & - & - & 1 & 1 \\
\hline EN & 2 & - & 1 & - & 2 & - & - & 14 & 19 \\
\hline $\mathrm{AL}$ & 1 & - & - & - & - & - & - & 2 & 3 \\
\hline $\mathrm{HN}$ & 1 & - & 1 & - & - & - & - & 3 & 5 \\
\hline $\mathrm{T}$ & - & - & - & - & - & - & - & 1 & 1 \\
\hline EV & - & - & 4 & - & - & 1 & - & 14 & 19 \\
\hline An & - & - & - & - & - & - & - & 2 & 2 \\
\hline SM & - & - & 2 & - & - & - & - & - & 2 \\
\hline TT & - & - & 1 & - & - & - & - & 2 & 3 \\
\hline GL / EC & - & - & - & - & 1 & - & 1 & 7 & 9 \\
\hline GL / EN & - & - & - & - & - & - & - & 2 & 2 \\
\hline GL / AL & - & - & - & - & - & - & 1 & - & 1 \\
\hline GL / HN & - & - & 1 & - & - & - & - & 1 & 2 \\
\hline GL / T & - & - & - & - & - & - & - & 1 & 1 \\
\hline $\mathrm{IB} / \mathrm{HN} / \mathrm{AL} / \mathrm{EN}$ & - & - & - & - & 1 & - & - & - & 1 \\
\hline $\mathrm{EC} / \mathrm{EN} / \mathrm{HN}$ & - & - & - & - & 1 & - & - & - & 1 \\
\hline $\mathrm{EN} / \mathrm{EC} / \mathrm{EH}$ & - & - & - & - & 1 & - & - & 1 & 2 \\
\hline $\mathrm{EC} / \mathrm{EN}$ & 1 & - & - & - & - & - & - & 6 & 7 \\
\hline GL / HN / TT & 1 & - & - & - & - & - & - & - & 1 \\
\hline $\mathrm{EC} / \mathrm{EV}$ & 1 & - & 1 & - & 1 & - & - & - & 3 \\
\hline $\mathrm{EN} / \mathrm{IB}$ & - & - & - & - & - & - & - & 2 & 2 \\
\hline SS & - & - & 1 & - & 1 & - & - & - & 2 \\
\hline $\mathrm{EN} / \mathrm{TT}$ & - & - & - & - & - & - & - & 1 & 1 \\
\hline $\mathrm{EC} / \mathrm{TT}$ & - & - & - & - & - & - & - & 1 & 1 \\
\hline $\mathrm{AL} / \mathrm{TT} / \mathrm{SS}$ & - & - & - & - & - & - & - & 1 & 1 \\
\hline $\mathrm{AL} / \mathrm{EC}$ & - & - & - & - & - & - & - & 1 & 1 \\
\hline $\mathrm{EC} / \mathrm{EN} / \mathrm{AL}$ & - & - & - & - & - & - & - & 3 & 3 \\
\hline GL / TT & - & - & 1 & - & - & - & - & 1 & 2 \\
\hline GL / TT / AL & - & 1 & - & - & - & - & - & - & 1 \\
\hline EN / EV & - & - & - & - & 1 & - & - & - & 1 \\
\hline \multirow[t]{2}{*}{ Total presenting } & 23 & 2 & 21 & 1 & 19 & 1 & 6 & \multirow[t]{2}{*}{140} & \multirow[t]{2}{*}{213} \\
\hline & & & & 230 & & & & & \\
\hline Total & 82 & 5 & 78 & 15 & 34 & 5 & 11 & 770 & 1,000 \\
\hline
\end{tabular}

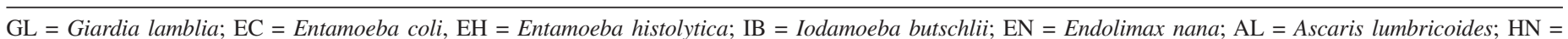
Hymenolepis nana; $\mathrm{T}=$ Taenia $\mathrm{sp} ; \mathrm{EV}=$ Enterobius vermicularis; $\mathrm{An}=$ Ancylostomid; $\mathrm{SM}=$ Schistosoma mansoni; $\mathrm{TT}=$ Trichuris trichiura .

Uberlândia-MG, Brazil prevalence of Ascaris lumbricoides (1.0\%) and Trichuris trichiura (1.0\%), much low than global prevalence indexes ${ }^{25}$. These data are in agreement with our data and are attributed to the public investments in basic sanitation and advisement of population through education.

CHIEFFI et al. (1988) observed occurrence of Ancylostomid in only $1.3 \%$ of the samples assessed in the city of Guarulhos, SP, Brazil while
MUNIZ-JUNQUEIRA \& QUEIRÓZ (2002) did not observe the occurrence of Ancylostomid in children younger than six years in the city of Brasília, Brazil. This fact was attributed to the urbanization and improvement of general life conditions in the last decades. In our study, in fact, we observed only two children with Ancylostomid.

The present study showed that only one child younger than one year had enteroparasite. According to CARLIER \& TRUYENS (1995) this 


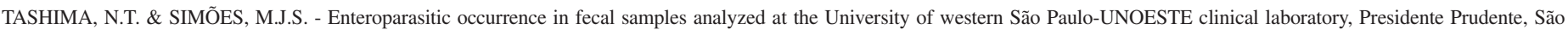
Paulo State, Brazil. Rev. Inst. Med. trop. S. Paulo, 46(5):243-248, 2004.

Table 3

Relationship between parasitism and diarrhea. Presidente Prudente-SP, 2001

\begin{tabular}{lcccc}
\hline Parasitism & \multicolumn{3}{c}{ Diarrhea } & Total \\
\cline { 2 - 4 } & Always & Sometimes & NO & \\
\hline Yes & 3 & 46 & 164 & 213 \\
No & 26 & 66 & 695 & 787 \\
Total & 29 & 112 & 859 & 1000 \\
\hline
\end{tabular}

$\chi^{2}=17.72 ; \mathrm{p}<0.01$

may be due to immunological responses as a consequence of antibodies transferred by mothers previously immunized to their sons.

ROCHA et al. (2000) states that the occurrence of schistosomiasis is low in children in school age. In fact, the two cases we found $(0.2 \%)$ occurred in people emigrated from contaminated areas.

The most frequent parasite association was Giardia lamblia and Entamoeba coli $(0.9 \%)$, followed by Entamoeba coli and Endolimax nana $(0.7 \%)$. FERREIRA et al. (2000) also observed that the association between two parasites was less frequent and the association between three or more parasites was not found. Nevertheless we found a very small proportion $(0.3 \%)$ of children with three parasites.

The relationship between incoming and giardiasis reveals a greater frequency of this protozoan in the lower income population, but also occurred in the class with familiar income greater than five minimum wages, according to MARZOCHI \& CARVALHEIRO (1978). When evaluating age and diagnostic we observed that the most frequent parasite, Giardia lamblia, was more prevalent in children from one to four years old, but did not occur in children younger than one year. COSTAMACEDO \& REY (2000) state the importance of the maternal milk in decreasing childhood parasitism. Experiments with human milk revealed the occurrence of an enzyme with giardicide properties and so, the maternal milking could contribute to enteroparasites control in the suckling. The increase in parasitism with age is attributed to the lack of good hygiene practices and absence of immunity to new infections ${ }^{13,14,18,27}$. According to COSTA-MACEDO et al. (1999), the increasing prevalence according to children aging may be due to the increase in their mobility and exposition to the environment. This information is in agreement with the findings in the present study. In addition, IXTA-RODRIGES et al. (1993) states that the increase in the frequency of enteroparasitosis in elderly children is due to the fact they feed outdoors, usually food with low nutritive value and generally prepared improperly, exposing them to more risks of contamination.

Although the most frequent protozoa was Giardia lamblia, most of the children did not had symptoms. This is in agreement with other statements that giardiasis has no symptoms in the majority of the cases. Among the complaints, the most frequent was diarrhea, which is one of the symptoms of this disease.

It is interesting to notice that the second most frequent protozoan was Entamoeba coli. Among 39 children that presented this parasite, 32 did not relate symptoms, which is in agreement with other previous observations. The same occurred with Endolimax nana, the third most frequent protozoan, which is also a enterocommensal.

The most frequent helminth, Enterobius vermicularis occurred in 19 cases, from which 14 had no symptoms (Table 2). This is also in agreement with the literature, because is asymptomatic in the majority of cases, and the patient only realize that have the parasite when feels an anal itch mainly at night.

It is interesting to notice that while ascaridiasis and trichuriasis occurrence have decreased these days, the occurrence of giardiasis has increased significantly. This was also noticeable at samples assessed at Instituto Adolfo Lutz at São Paulo State ${ }^{5,7}$. Our data are in agreement with those of CHIEFFI et al. (1982) and CHIEFFI (1986), who observed a high prevalence of giardiasis and low prevalence of ascaridiasis and trichuriasis. The low occurrence of enteroparasitosis in our samples may be attributable to the amplification of public systems of water treatment and distribution and sewerage system. Most of the children studied had toilet inside their houses and also received treated water from public net. According to the question form, only six children drink water from well. TSUYUOKA et al. (1999), found that children who have no access to toilet had a high prevalence of enteroparasitosis.

\section{FINAL CONSIDERATIONS}

Our results show that, $21.3 \%$ of the children with 0 to 12 years old attended at the Clinical Analysis Laboratory - University of western São Paulo (UNOESTE), Presidente Prudente, Brazil presented the occurrence of enteroparasitosis. This result was not related to familiar incomes, but, although not statistically significant, there was a tendency of less occurrence of parasitosis in children whose families had greater gains. The greatest occurrence was in children from one to four years old and the most frequent parasite in this group was Giardia lamblia. Among children with parasites, only $23 \%$ had some symptom and the most frequent was diarrhea.

Most of the children presented only one parasite, with Giardia lamblia as the most frequent. When more than one parasite occurred, the most frequent association was Giardia lamblia and Entamoeba coli.

\section{RESUMO}

\section{Ocorrência de enteroparasitas em amostras fecais analisadas no Laboratório Clínico da UNOESTE, Presidente Prudente, Estado de São Paulo, Brasil}

O objetivo deste estudo foi estimar a ocorrência de enteroparasitoses em crianças de 0 a 12 anos de Presidente Prudente - SP por meio de exames parasitológicos, associada ao perfil sócio-econômico da população. Um questionário foi aplicado com o objetivo de conhecer as seguintes variáveis: idade do paciente, sexo, tipo de assistência médica, características da habitação, abastecimento de água, destino dos dejetos, do lixo, uso de calçados e sinais clínicos. Para a elaboração da estrutura de banco de dados e sua análise, utilizou-se o programa EPI INFO 6 (Versão 6.04b) após pré-codificação dos dados. Das 1.000 amostras estudadas, $78,7 \%$ das crianças não apresentaram parasitas e 21,3\% apresentaram alguma espécie de parasita. O protozoário mais freqüente 


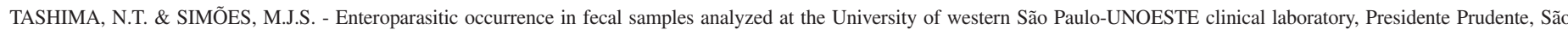
Paulo State, Brazil. Rev. Inst. Med. trop. S. Paulo, 46(5):243-248, 2004.

foi Giardia lamblia (7,3\%) seguido de Entamoeba coli $(3,9 \%)$. Os helmintos mais freqüentes foram Enterobius vermicularis (1,9\%), seguido de Hymenolepis nana $(0,5 \%)$. A associação mais freqüente foi Giardia lamblia e Entamoeba coli $(0,9 \%)$.

\section{REFERENCES}

1. AMATO NETO, V.; CAMPOS, R. \& FERREIRA, C.S. - Diagnóstico das parasitoses intestinais pelo exame de fezes. São Paulo, Atheneu, 1963.

2. BRAGA, L.L.; LIMA, A.A.; SEARS, C.L. et al. - Seroepidemiology of Entamoeba histolytica in a slum in northeastern Brazil. Amer. J. trop. Med. Hyg., 55: 693-697, 1996.

3. CANCRINI, G.; BORTOLONI, A.; PARADISI, F. \& NUNES, L.E. - Parasitological observations on three Bolivian localities including rural communities, cities and institutions. Ann. trop. Med. Parasit., 83: 591-594, 1989

4. CARLIER, Y. \& TRUYENS, C. - Influence of maternal infections of offspring resistence towards parasites. Parasit. today, 11: 94-99, 1995.

5. CHIEFFI, P.P.; WALDMAN, E.A.; WALDMAN, C.C.S. et al. - Aspectos epidemiológicos das enteroparasitoses no estado de São Paulo, Brasil. Rev. paul. Med., 99: 34-36, 1982.

6. CHIEFFI, P.P.; WALDMAN, E.A.; DIAS, R.M.D.S. et al. - Enteroparasitoses no município de Guarulhos, SP, Brasil. 1. Prevalência de infecção entre escolares residentes no bairro de Taboão, em junho de 1984. Rev. Inst. Adolfo Lutz, 48: 75-80, 1988.

7. CHIEFFI, P.P. - Aspectos epidemiológicos das geohelmintíases no Estado de São Paulo, Brasil. Arq. med. Hosp. Fac. Ciênc. Méd. S. Casa S. Paulo, 6: 61-64, 1986.

8. COSTA-GURGEL, M.S.; NUNES, M.P.O.; NUNES, J.F.L. \& SILVA, E.M.A. Prevalência de enteroparasitoses em Natal: rotina coproscópica da parasitologia clínica, UFRN. Rev. bras. Anál. clín., 24: 103-107, 1992

9. COSTA-MACEDO, L.M.; COSTA, M.C. \& ALMEIDA, L.M. - Parasitismo por Ascaris lumbricoides em crianças de dois anos: estudo populacional em comunidade do Estado do Rio de Janeiro. Cadern. Saúde públ., 15: 173-178, 1999.

10. COSTA-MACEDO, L.M. \& REY, L. - Aleitamento e parasitismo intestinal maternoinfantil. Rev. Soc. bras. Med. trop., 33: 371-375, 2000.

11. DE ONIS, N.; MONTEIRO, C.; AKRÉ, J. \& CLUGSTON, G. - The worldwide magnitude of protein-energy malnutrition: an overview from the WHO global database on child growth. Bull. Wld. Hlth Org., 71: 703-712, 1993.

12. FERREIRA, C.B. \& MARÇAL Jr., O. - Enteroparasitoses em escolares do distrito de Martinésia, Uberlândia, MG: um estudo Piloto. Rev. Soc. bras. Med. trop., 30: 373-377, 1997.

13. FERREIRA, M.U.; FERREIRA, C.S. \& MONTEIRO, C.A. - Tendência circular das parasitoses intestinais na infância na cidade de São Paulo (1984-1996). Rev. Saúde públ. (S. Paulo), 34: 73-83, 2000.

14. GOIA, I. - Prevalência de parasitoses intestinais entre os usuários do Centro de Saúde do distrito de Sousas, Campinas, SP (1986-1990). Rev. Soc. bras. Med. trop., 25: 177 $182,1992$.

15. HOFFMAN, W.; PONS, J.L. \& JANER, J.L. - The sedimentation-concentration methods in Shchistosoma mansoni. Puerto Rico J. publ. Hlth, 9: 283-291, 1934.

16. IXTA-RODRIGUES, O.; FUENTE, G.L.; RODRIGUES-GARCIA, G. \& BARRIOSPOMPA, M. - Frecuencia de parásitos intestinales y bacterias productoras de diarrea en niños de un hospital de zona. Rev. lat.-amer. Microbiol., 35: 137-142, 1993.
17. JEKEL, J.F.; ELMORE, J.G. \& KATEZ, D.L. - Epidemiologia, bioestatística e medicina preventiva. Porto Alegre, Artes Médicas Sul, 1999.

18. JOKIPII, A.M.M. \& JOKIPII, L. - Prepatency of giardiasis. Lancet, 1: 1095-1097, 1977.

19. KOBAYASHI, J.; HASEGAWA, H.; FORLI, A.A. et al. - Prevalence of intestinal parasitic infection in five farms in Holambra, São Paulo, Brazil. Rev. Inst. Med. trop. S. Paulo, 37: 13-18, 1995.

20. LA VIA, W.V. - Parasitic gastroenteritis. Pediat. Ann., 23: 556-560, 1994.

21. MACHADO, R.C.; MARCARI, E.L.; CRISTANTE, S.F.V. \& CARARETO, C.M.A. Giardíase e helmintíase em crianças de creches e escolas de primeiro e segundo graus (públicas e privadas) da cidade de Mirassol (SP, Brasil). Rev. Soc. bras. Med. trop., 32: 697-704, 1999.

22. MARZOCHI, M.C.A. \& CARVALHEIRO, J.R. - Estudos dos fatores envolvidos na disseminação dos enteroparasitas. III. Distribuição de algumas enteroparasitoses em dois grupos populacionais de Ribeirão Preto, São Paulo, Brasil. Rev. Inst. Med. trop. S. Paulo, 20: 31-35, 1978

23. MUNIZ-JUNQUEIRA, M.I. \& QUEIRÓZ, E.F.O. - Relationship between protein-energy malnutrition, vitamin A and parasitosis in children living in Brazilia. Rev. Soc. bras. Med. trop., 35: 133-141, 2002.

24. NAZER, H.; GREER, W.; DONELLY, K. et al. - The need for three stool specimens in routine laboratory examinations for intestinal parasites. Brit. J. clin. Pract., 47: 76$78,1993$.

25. NEVES, D.P. - Enterobius vermicularis. In: NEVES, D.P.; MELO, A.L.; GENARO, O. \& LINARDI, P.M., ed. Parasitologia humana. São Paulo, Editora Atheneu, 2000. p. 257-261.

26. PEREZ, A.C.; AREZA, A.C.; UELBA, O. J. et al. - Epidemiology of children's intestinal parasitism in the Guadalquivir Valley, Spain. Rev. esp. Salud publ., 71: 547-552, 1997.

27. ROCHA, R.S.; SILVA, J.G.; PEIXOTO, S.V. et al. - Avaliação da esquistossomose e de outras parasitoses intestinais, em escolares do município de Bambuí, Minas Gerais, Brasil. Rev. Soc. bras. Med. trop., 33: 431-436, 2000.

28. SAWITZ, W.G. \& FAUST, E.C. - The probability of detecting intestinal protozoa by successive stool examinations. Amer. J. trop Med., 22: 131-136, 1942.

29. STEPHENSON, L.S. - Los helmintos importante factor de malnutríción. Foro Mundial de Salud, 15: 184-187, 1994

30. TSUYUOKA, R.; BAILEY, J.W.; GUIMARÃES, A.M.A.N.; GURGEL, R. \& CUEVAS, L.E. - Anemia and intestinal parasitic infections in primary school students in Aracaju, Sergipe, Brazil. Cadern. Saúde públ., 15: 413-421, 1999.

31. UNICEF - Situação mundial da infância. Brasília, UNICEF, 1998.

32. VALLADA, E.P. - Manual de exame de fezes, coprologia e parasitologia. Rio de Janeiro, Livraria Atheneu, 1988.

33. WHO - Epidemiologia em microcomputadores: um sistema de processamento de textos, banco de dados e estatísticas. [Programa de Computador]. Atlanta, OPAS/ WHO, 1997.

Received: 25 November 2003

Accepted: 20 September 2004 